\title{
Labyrinthe
}

\section{2 novembre 2007 | France Culture, "À plus d'un titre" (entretien de David Schreiber et Pierre Savy avec Jacques Munier)}

\section{CpenEdition}

\section{Journals}

Édition électronique

URL : http://journals.openedition.org/labyrinthe/3053

DOI : $10.4000 /$ labyrinthe. 3053

ISSN : 1950-6031

Éditeur

Hermann

Édition imprimée

Date de publication : 21 décembre 2007

ISBN : 978-2-9526131-5-6

Référence électronique

« 2 novembre 2007 | France Culture, "À plus d'un titre" (entretien de David Schreiber et Pierre Savy avec Jacques Munier) », Labyrinthe [En ligne], $28 \mid 2007$ (3), mis en ligne le 07 novembre 2007, consulté le 24 avril 2019. URL : http://journals.openedition.org/labyrinthe/3053 ; DOI : 10.4000/labyrinthe.3053

Ce document a été généré automatiquement le 24 avril 2019

Propriété intellectuelle 
2 novembre 2007 | France Culture, "À plus d'un titre" (entretien de David Schreiber et Pierre Savy avec Jacques Munier) 